\title{
Correction to: Upregulation of selected HERVW loci in multiple sclerosis
}

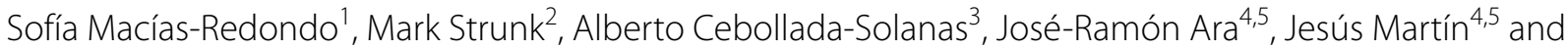 \\ Jon Schoorlemmer ${ }^{1,6,7^{*}}$
}

Correction to: Mob DNA 12, 18 (2021)

https://doi.org/10.1186/s13100-021-00243-1

Following the publication of the original article [1] the authors noticed the published Table 1 has a distorted headings and columns not in proper order.

The correct Table 1 is shown below. The original article [1] has been updated.

\begin{abstract}
Author details
${ }^{1}$ Instituto Aragonés de Ciencias de La Salud (IACS), C/Juan Bosco 13, 50009 Zaragoza, Spain. ${ }^{2}$ Sequencing and Functional Genomics, Aragon Biomedical Research Center (CIBA), Instituto Aragonés de Ciencias de La Salud (IACS), Zaragoza, Spain. ${ }^{3}$ Aragon Biomedical Research Center (CIBA), Instituto Aragonés de Ciencias de La Salud (IACS), Unidad de Biocomputación, Zaragoza, Spain. ${ }^{4}$ Instituto de Investigación Sanitaria de Aragón (IIS Aragón), Zaragoza, Spain. ${ }^{5}$ Department of Neurology, University Hospital Miguel Servet, Zaragoza, Spain. ${ }^{6}$ ARAID Foundation, Avda. de Ranillas 1-D, 50018 Zaragoza, Spain. ${ }^{7}$ Placental Pathophysiology and Fetal Programming Research Group del IISA, c/Juan Bosco 13, 50009 Zaragoza, Spain.
\end{abstract}

Published online: 11 August 2021

\section{Reference}

1. Macías-Redondo S, Strunk M, Cebollada-Solanas A, et al. Upregulation of selected HERVW loci in multiple sclerosis. Mob DNA. 2021;12:18. https:// doi.org/10.1186/s13100-021-00243-1.

The original article can be found online at https://doi.org/10.1186/s13100021-00243-1.

*Correspondence: jonas@araid.es

${ }^{7}$ Placental Pathophysiology and Fetal Programming Research Group del IISA, c/Juan Bosco 13, 50009 Zaragoza, Spain

Full list of author information is available at the end of the article

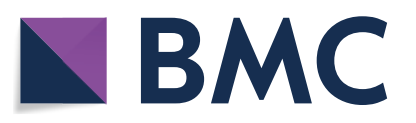

(c) The Author(s) 2021. Open Access This article is licensed under a Creative Commons Attribution 4.0 International License, which permits use, sharing, adaptation, distribution and reproduction in any medium or format, as long as you give appropriate credit to the original author(s) and the source, provide a link to the Creative Commons licence, and indicate if changes were made. The images or other third party material in this article are included in the article's Creative Commons licence, unless indicated otherwise in a credit line to the material. If material is not included in the article's Creative Commons licence and your intended use is not permitted by statutory regulation or exceeds the permitted use, you will need to obtain permission directly from the copyright holder. To view a copy of this licence, visit http://creativecommons.org/licenses/by/4.0/. The Creative Commons Public Domain Dedication waiver (http://creativeco mmons.org/publicdomain/zero/1.0/) applies to the data made available in this article, unless otherwise stated in a credit line to the data. 
Table 1 Clinical features of MS patients included in this study

$\begin{array}{llllll}\text { Case } & \text { MS subtype } & \text { Age } & \text { Sex } & \text { Status } & \text { RRM } \\ & & & & & \\ \text { RSM-49 } & \text { CIS } & 25 & \text { F } & \text { NA } & \text { NO } \\ \text { RSM-58 } & \text { CIS } & 44 & \text { F } & \text { A } & \text { YES } \\ \text { RSM-70 } & \text { CIS } & 47 & \text { F } & \text { A } & \text { YES } \\ \text { RSM-73 } & \text { CIS } & 39 & \text { M } & \text { NA } & \text { YES } \\ \text { RMS-103 } & \text { CIS } & 53 & \text { F } & \text { NA } & \text { YES } \\ \text { RMS-114 } & \text { CIS } & 44 & \text { M } & \text { NA } & \text { NO }\end{array}$

No MS Controls Age Sex

$\begin{array}{lll}\text { RMS-3 } & 36 & \mathrm{~F} \\ \text { RMS-15 } & 31 & \mathrm{M} \\ \text { RMS-23 } & 46 & \mathrm{~F} \\ \text { RMS-30 } & 46 & \mathrm{M} \\ \text { RSM-42 } & 39 & \mathrm{M} \\ \text { RSM-46 } & 44 & \mathrm{M} \\ \text { RSM-62 } & 29 & \mathrm{~F} \\ \text { RSM-72 } & 46 & \mathrm{M} \\ \text { RSM-80 } & 48 & \mathrm{M} \\ \text { RSM-98 } & 47 & \mathrm{M} \\ \text { RSM-99* } & 17 & \mathrm{M} \\ \text { RSM-102* } & 56 & \mathrm{~F} \\ \text { RSM-104 } & 44 & \mathrm{M} \\ \text { RMS-106* } & 59 & \mathrm{M} \\ \text { RMS-109 } & 45 & \mathrm{M} \\ \text { RMS-112 } & 47 & \mathrm{~F} \\ \text { RMS-113 } & 28 & \mathrm{M} \\ \text { RMS-118 } & 30 & \mathrm{~F}\end{array}$

Clinical data of patients whose PBMCs were analyzed for HERVW expression. Median ages for both patients and controles groups were 44 years (mean and SEM are $42,0 \pm 4,25$ and $40,4 \pm 1,94$ for patient and control groups, respectively)

A/NA status refers to active and non-active patients respectively. Posterior progression towards MS diagnosis (RRMS) is indicated for all CIS cases. Samples analyzed by NGS are marked in blue. median ages in these groups are 44 year for patients and 47 years for controls. * indicates samples only analyzed by NGS 